UDC: $378.147: 811.111: 371.212$

DOI: https://doi.org/10.24195/2414-4665-2017-2-11

Olena Karpova,

PhD (Candidate of Pedagogical Sciences), associate professor, Department of Foreign Languages,

Odesa National Economic University,

8, Preobrazhenska Str., Odessa, Ukraine

\title{
THE USE OF WEB-CASE IN TEACHING ENGLISH TO STUDENTS MAJORING IN ECONOMICS
}

In the article the notion of «a web-case» has been defined, its structure and the peculiarities of its use in the process of teaching English have been presented. The analysis of theoretical resources and a survey have been conducted that approved the necessity to develop new forms, methods and tools of teaching English with the use of multimedia technologies. The use of a web-case in teaching English to future economists has been proved. The empirical data show the effectiveness of implementation of a web-case and other interactive tasks in the educational process.

Keywords: web-case, Internet-technologies, interactive learning, individual work, interdisciplinary approach.

\section{Introduction}

In the National Strategy of Educational Development in Ukraine for 2012-2021 it is emphasized that in the framework of Ukraine's formation as an independent country with its crucial changes in all its spheres of public life the reforms in the national system of education require solving sharper problems that slow down the development of the educational system and prevent from opportunities to provide a new quality of education. They include exceptionable content of education, its national standards, curricula, syllabi and textbooks, in particular; lack of structure and content orientation of the system of education towards market needs and modern economic challenges; a slow process of humanization, ecologization and informatization of the system of education as well as the implementation of innovative methods, information and communication technologies into the educational process. According to the tasks set in the field of education, it is important to provide a stable development and a qualitative breakthrough in the national system of education. It requires modernization of educational, scientific, methodical and equipment base in the higher educational establishments.

One of the most important challenges of modern education is reconsideration and update of methods of teaching English to future economists. Nowadays the level of the English language of students majoring in economics very often does not correspond to the Effective Operational Proficiency level that is mentioned in the Common European Framework of References for Languages.

The problem of teaching a foreign language to economics students has been studied by Y. Avsiukevych, O. Bigych, O. Dehtiariova, T. Karayeva, T. Korzh, Z. Kornyeva, O. Penkova, V. Tytova, et.al. The scholars emphasize the importance of new educational technologies implementation into the process of foreign languages teaching.

The use of multimedia technologies in teaching a foreign language was researched by Ya. Bulakhova, N. Klevtsova, T. Kolesova, A. Lazareva, O. Paliy, O. Tarnopolskyi [4], et.al. The combination of different methods of teaching speaking, reading, listening and writing in a foreign language with modern tools of ICT contributes to the activization of the educational process and the formation of foreign professional communicative competence of students.

Some scholars paid special attention to the issue of teaching a foreign language to economics students using educational projects and game forms (L. Vygotsky, O. Leontiev, D. Bubnova, A. Bunina, V. Martyniuk, J. Richards, G. Yavorska, et.al.) as well as the case study method (J. van Maanen, J. Erskine, M. Reichelt, A. Watson, O. Sidorenko, Yu. Surmin, L. Shtefan, et. al.) that foster the development of teamwork skills, critical thinking, the formation of research skills as well as self-study skills. The scholars believe that modeling real business situations, especially due to the combination of roleplaying, imitative and organizational-activity aspects of a game, helps to combine educational activity with a professional environment in order to form professional knowledge and skills of future economists [2].

Despite a great number of methodical works, the issue of using multimedia technologies, including Internettechnologies, in the process of teaching a foreign language to future economists is still acute and understudied.

The present paper aims to define the notion «webcase», its structure and peculiarities of its use in the process of teaching English to students majoring in economics. The following tasks have been set:

1) to review scientific and pedagogical literature in order to study the current state of teaching English by means of new technologies;

2) to make a definition of the notion «web-case» and distinguish its components;

3) to approve the effectiveness of using web-case in the educational process.

To achieve the goal and implement the tasks set, the following research methods were used: theoretical (analysis, comparison, generalization, systematization of literature to make a definition of the notion «web-case» and the 
research of the current condition of the issue), empirical (diagnostic methods: observation, questionnaires, discussions, solving cases; pedagogical experiment to study the effectiveness of using multimedia technologies and webcases; as well as statistical methods: statistics methods to assess the results of the pedagogical experiment).

The pedagogical experiment that was focused on studying the effectiveness of using multimedia technologies in teaching English to economics students (the sample involved 188 students) was carried out from 2008 to 2014 and consisted of three stages that included the analysis of scientific, psychological and pedagogical literature, the outline of the key definitions of the research, the study of pedagogical experience and modern methods of teaching English in higher educational establishments and the analysis of the results obtained.

First of all, in order to study the current situation of using multimedia technologies in teaching a foreign language to students majoring in economics, a questionnaire was offered to Foreign Languages teachers and undergraduate students (a total of 180 persons). According to the results of the survey, it was found out that one of the main problems of using multimedia technologies in the classroom, from the teachers' point of view ( $46 \%$ of respondents), was bad connection or even no access to the Internet. However, the Internet was actively used in the process of mastering English by $90 \%$ of the students when searching for resources for reports, articles, presentations, creative tasks, terms and texts translation as well as for learning grammar and doing online tests. Despite this, most of the teachers ( $72 \%$ of respondents) did not implement online learning or use the Internet for getting a feedback from students and keeping in touch. It should be mentioned that the teachers offered doing such kinds of classroom and individual Internet-based tasks as searching for information for writing reports, articles; using edictionaries, online tests, video and audio material online, etc. along with making presentations, solving cases, playing linguistic games, etc. They believed that the best teaching methods and techniques that helped to implement an interdisciplinary approach into the educational process were discussions, business games and case studies. That was proved by the students' answers that the interdisciplinary principle was used during English lessons (67\% of respondents). As for using the case study method while studying English, $47 \%$ of the students said that the method had not been used at all, $30 \%$ of the students approved its usage in the classroom and $22 \%$ of them replied that they did not know anything about it.

Therefore, the results of the survey have approved the importance and necessity of implementing multimedia technologies, developing new methods and tools for teaching a foreign language as well as interactive tasks and activities.

Thus, despite making presentations, solving a webquest and doing other interactive tasks for teaching and studying English using multimedia technologies in the experimental group, a new type of case study method that can be classified according to the form of its presentation as "a webcase" was offered to students. The creation of such a kind of task was caused by the popularity of case studies in the world leading economic universities and business schools and the active use of the Internet by the professionals in the fields of Economics and Management.

A web-case was defined as a format of activity-based learning environment created by ICT tools, which contains structured materials that are used by students to analyze business situations in order to form skills of solving practical tasks. The peculiar feature of a web-case was that all the tasks were uploaded to the university website so that the students could do it online with the help of the links to the official websites of companies, articles and other electronic documents.

A web-case has the following structure:

- Introduction (or Background) that contains the information about the activities of two companies with the links to their official websites.

- The main part (Task), in which the problem that the two companies faced is

revealed.

- Conclusion, which involves writing a business email or making a multimedia presentation by the group to show the results and the solution of the problem.

It is important to point out that the implementation of the case study method included three stages: diagnostic (to find out the level of English, relations between the students within a group, the need to form the required skills, etc.), preparatory (the formation of homogeneous groups of 3-5 people (groups that have the same level of English, share common interests, etc.) or heterogeneous teams; task setting as well as timing, clarification of tasks for teams, assessment criteria, rules and so on), the process of solving a web-case; assessment of results and achievements both of the whole team and the contribution of every member in particular.

Thus, while solving a web-case the teams had to analyze the problem (case) from different angles (economic, geographical, political, financial, etc.), realize the situation that had occurred and discuss the best possible solution of the problem and its effectiveness.

For the solution of a web-case in a more efficient way the following steps were offered to the students:

1. Learn the activities of the two companies.

2. Think critically about the situation occurred taking into consideration all

the possible advantages and disadvantages of solving the problem.

3. Define the problem and analyze different points of view using an interdisciplinary approach.

4. Generate alternative solutions and dwell upon the criteria that can be useful

to set priorities taking into account all the given details, time scale, etc.

5. Present your decision and ideas in the form of a

PowerPoint presentation or

writing a business e-mail.

The whole process of doing a web-case can be presented as follows: 


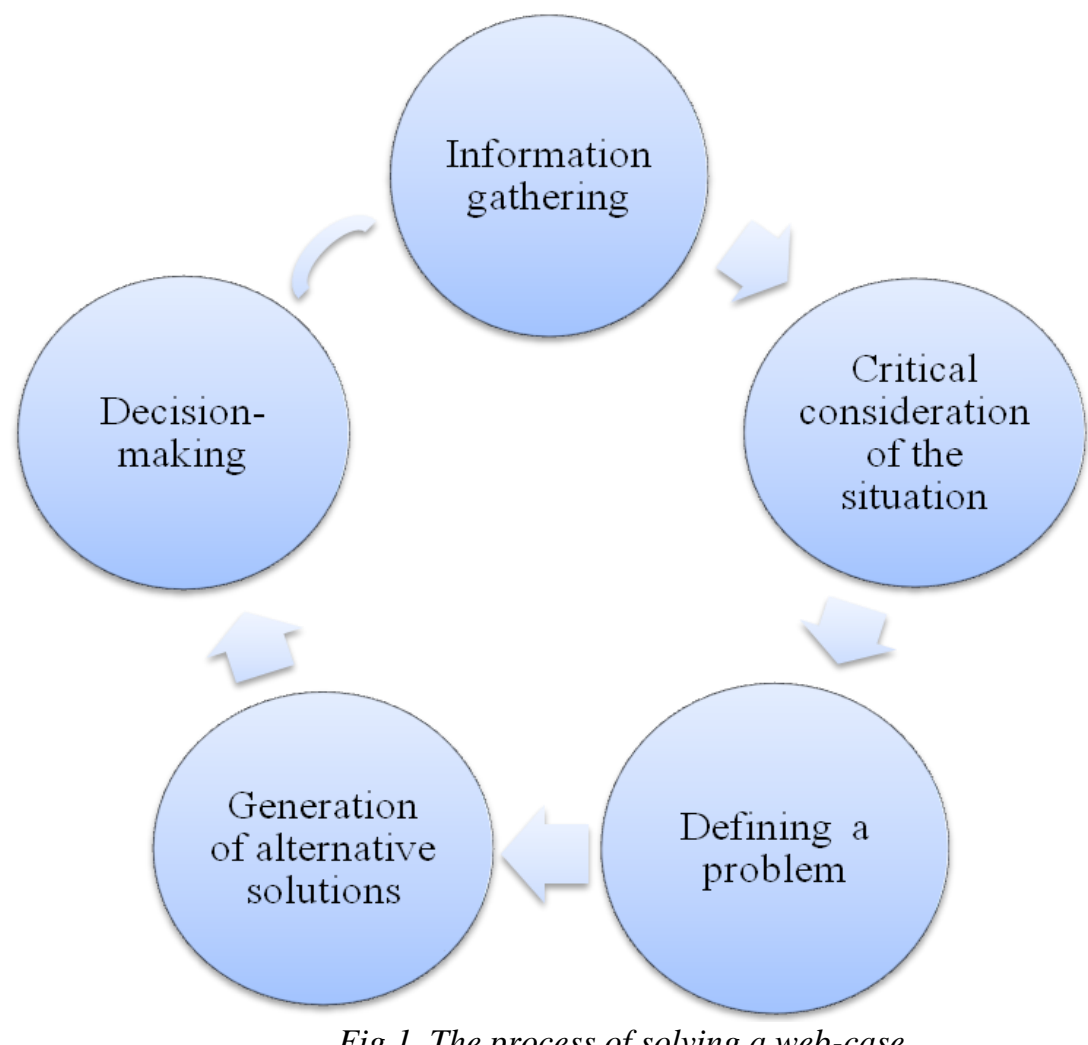

Fig.1. The process of solving a web-case

As a rule, case studies do not have a final solution to the problem due to the fact that they are close to the realia of business environment and most of the possible solutions can be appropriate. Therefore, it is often impossible to define immediately whether the decision is correct in the long run because it requires time to measure its effectiveness. However, at the early stage the students had the answer to a web-case with a link to the official website.

As an example, to have a deeper understanding of the topic «Mergers and Acquisitions» the students were offered to do a web-case on the university website [5] First of all, the group was divided into 4-5-person subgroups (teams) and learned the rules, keywords and tasks. Then, the teams chose one of the offered real stories of the world's most famous takeovers like Unilever and Ben\&Jerry, Walt Disney and Pixar and others.

In the «Background» part they learned about the history, activities and products or services of the two companies clicking on the links provided. After that they looked through the «Problems» part and considered electronic financial statements of the companies, articles that highlighted the problems and prospects of the merger, possible solutions, advantages and disadvantages of the merger or takeover for both companies using the links to online resources or searching for new information themselves.
In the «Task» part the students did the tasks provided and made a final decision. Finally, in «Writing» they were given a task to write a business e-mail with their decision giving reasons. Whether the task was done correctly they could check their answer using the link to the official source at the end of a web-case.

When all the teams presented their findings, their teamwork was assessed, the decisions made were discussed and the keywords of the topic were revised. The students mentioned that doing a web-case was a good opportunity to learn more about the activities of world famous brands, their strategies of running business, widen their thesaurus with economic and business terms, improve their reading skills of electronic economic sources, analyze business situations in a better way and work in a team.

The criteria of web-case assessment were the following: the decision made that demonstrated the use of the analytical and creative approach, timing and teamwork.

At the final stage of the experiment the students who were from the very beginning divided into the control group (92 persons) and the experimental groups (96 persons) made a test that approved that the use of multimedia technologies, namely a web-case and other interactive tasks contributed to the improvement of their command of the English language. Using the ordinal scale of measurement the following table was drawn up: 
Table 1

The students' levels of English in the control and experimental groups (after the experiment)

\begin{tabular}{|c|c|c|c|c|}
\hline \multirow{2}{*}{ Level } & \multicolumn{2}{|c|}{ the control groups } & \multicolumn{2}{c|}{ the experimental groups } \\
\cline { 2 - 5 } & number & percentage & number & percentage \\
\hline Basic & 40 & 43,50 & 19 & 19,80 \\
\hline Intermediate & 39 & 42,40 & 53 & 55,20 \\
\hline Advanced & 13 & 14,10 & 24 & 25,00 \\
\hline$\Sigma$ & 92 & 100 & 96 & 100 \\
\hline
\end{tabular}

The results obtained show that the number of students of the experimental group with Intermediate and Advanced levels of English has significantly increased. The number of students, who had the Basic level, has decreased by $36 \%$, while in the control group this indicator was only $13 \%$.

Therefore, the implementation of the case study method with multimedia technologies has fostered the formation of foreign professional communicative competence and comprehensive personality development of students. It has also enabled students, in our opinion, to be ready for future professional activity in the fields of Economics and Management; to use new technologies for educational and research purposes, to develop critical thinking and creativity, to acquire teamwork skills.

\section{REFERENCES}

1. Ishchuk, N. Yu. (2006). Zastosuvannya zasobiv multymedia $\mathrm{u}$ protsesi pidhotovky ekonomistiv $\mathrm{u}$ vyshchykh navchalnykh zakladakh I-II rivniv akredytatsiy [Using multimedia technologies in the process of training economists at higher educational institutions]. Extended abstract of candidate's thesis. Vinnytsia [in Ukrainian].

2. Zakharchenko, N. V. (2006). Pedahohichni umovy vykorystannya dilovykh ihor u pidhotovtsi maybutnikh ekonomistiv [Pedagogical terms of the use of business games in preparation of future economists]. Candidate's thesis. Vinnytsia [in Ukrainian].

3. Pinchuk, O. P. (2004). Problema vyznachennya multymedia $\mathrm{v}$ osviti: tekhnolohichnyy aspekt [The issue of multimedia technologies in education: technological aspect]. Novi tekhnolohiyi navchannya: nauk.-metod. zb. -

\section{ЛІТЕРАТУРА}

1. Іщук Н. Ю. Застосування засобів мультимедіа у процесі підготовки економістів у вищих навчальних закладах I-II рівнів акредитації : автореф. дис. на здобуття наукового ступеня канд. пед. наук : 13.00.04«Теорія та методика професійної освіти» / Н. Ю. Іщук. - Вінниця, 2004. - 20 с.

2. Захарченко Н. В. Педагогічні умови використання ділових ігор у

підготовці майбутніх економістів: дис. на здобуття наукового ступеня канд. пед. наук : 13.00.04 - «Те-
The absence of case studies in syllabi, the reduction of classroom studies and lack of methodical and didactic literature can be mentioned among the obstacles to the implementation of multimedia technologies that took place during the experiment.

\section{Conclusion}

To sum up, the use of a web-case in teaching English to students majoring in economics helped activate and revive the educational process, widen and revise the key concepts and economic terms, develop reading, speaking and writing skills that led to the formation of foreign professional communicative competence.

Further research is planned to be done in the field of distance learning of a foreign language as well as online learning.

New teaching technologies: collection of scientific works. Kyiv, Lenvit Publ. [in Ukrainian].

4. Tarnopolskyi, O. B., Kozhushko, S. P. (2004). Metodika obucheniya angliyskomu yazyku dlya delovogo obshcheniya: uch. posob. [Methodology of teaching the English language for business communication: textbook]. Kyiv, Lenvit Publ. [in Russian].

5. Karpova, O. O. Multimedia Technologies in Teaching Business English. Retrieved from: http://oneu.edu.ua/pages/cath/for_lang/businessenglish/we bcase.php [in English].

6. Warschauer, M., Shetzer, H., Meloni, C. (2000). Internet for English teaching. Alexandria, VA : TESOL [in English].

орія та методика професійної освіти» / Н. В. Захарченко. - Вінниця, 2006. - 240 с.

3. Пінчук О. П. Проблема визначення мультимедіа в освіті: технологічний аспект / О. П. Пінчук // Нові технології навчання : наук.-метод. зб. / [Кол. авт.]. - К. : Інститут інноваційних технологій і змісту освіти, 2007. - №46. - С. 55-58.

4. Тарнопольский О. Б. Методика обучения английскому языку для делового общения: уч. пособ. 
/ Тарнопольский О. Б., Кожушко С. П. - К. : Ленвит, 2004. - 192 c.

5.Multimedia Technologies in Teaching Business English [Електрон. pecypc] / O. Karpova. - ONEU.-
URL:

http://oneu.edu.ua/pages/cath/for_lang/ businessenglish/webcase.php

6. Warschauer M. Internet for English teaching / M. Warschauer, H. Shetzer, C. Meloni. - Alexandria, VA : TESOL, 2000. - 176 p.

Олена Олегівна Карпова, кандидат педагогічних наук, дочент кафедри іноземних мов, Одеський начіональний економічний університет, вул. Преображенська, 8, м. Одеса, Україна

\section{ВИКОРИСТАННЯ ВЕБ-КЕЙСУ У НАВЧАННІ АНГЛІЙСЬКОЇ МОВИ СТУДЕНТІВ-ЕКОНОМІСТІВ}

Однією з важливих освітніх проблем є впровадження сучасних технологій, переосмислення та оновлення форм, методів і засобів навчання англійської мови майбутніх економістів. Адже наразі рівень володіння англійською мовою студентів економічних спеціальностей здебільшого не відповідає професійному рівню, а результати анкетування довели необхідність упровадження мультимедійних технологій, розробки нових методів навчання іноземної мови, у тому числі й створення інтерактивних завдань, що й зумовило актуальність дослідження. Метою статті було розкрити сутність поняття «веб-кейс», його структуру та особливості використання у процесі навчання англійської мови майбутніх економістів. Для досягнення мети застосовувались такі методи дослідження: теоретичні (аналіз, порівняння, узагальнення, систематизація теоретичних положень для визначення змісту поняття «веб-кейс» і стану розробленості досліджуваної проблеми), емпіричні (діагностичні: спостереження, анкетування, бесіди, розв'язування кейсів; педагогічний експеримент) та методи математичної статистики для опрацювання результатів педагогічного експерименту. «Веб-кейс» було визначено як «формат навчально-діяльнісного середовища, створеного засобами IКТ, що містить структуровані матеріали, на основі яких студентами здійснюється аналіз бізнес-ситуацій з метою формування навичок розв'язання практичних завдань». Особливістю веб-кейсу було те, що завдання було розміщено на веб-сайті, тому студенти мали змогу виконувати завдання он-лайн, посилаючись на офіційні сайти компаній, електронні статті та інші документи в електронному вигляді. Автором дидактично обгрунтовано використання веб-кейсу в процесі навчання студентів-економістів англійської мови. Реалізація кейс-методу завдяки мультимедійним технологіям у процесі навчання англійської мови дала змогу забезпечити готовність студентів до майбутньої професійної діяльності в галузі економіки, управління та банківської справи, а також сформувати іншомовну професійну комунікативну компетенцію. Результати контрольного експерименту засвідчили, що використання веб-кейсу та інших інтерактивних завдань сприяло підвищенню рівня володіння англійською мовою студентів, розвитку критичного та творчого мислення, формуванню навичок командної роботи тощо.

Ключові слова: веб-кейс, Інтернет-технології, інтерактивне навчання, самостійна робота, міждисциплінарний підхід.

Submitted on February, 16, 2017

Reviewed by Doctor of Pedagogy, prof. T. Yablonska 